\title{
SINTESIS DAN UJI TOKSISITAS SENYAWA ANALOG KURKUMIN 3,5-BIS((E)-METOKSI BENZILIDEN)-1-(FENILSULFONIL)-PIPERIDIN-4-ON
}

\author{
E. N. Rahmawati ${ }^{1}$, H. Y. Teruna ${ }^{2}$, dan A. Zhamri ${ }^{2}$ \\ ${ }^{1}$ Mahasiswa Program Pascasarjana Kimia \\ ${ }^{2}$ Bidang Kimia Organik Jurusan Kimia \\ Fakultas Matematika dan Ilmu Pengetahuan Alam \\ Kampus Binawidya, Pekanbaru, 28293, Indonesia
}

Email: eninur.rahmawati@gmail.com

\begin{abstract}
A study has been conducted to synthesize analog of curcumin with base catalyzed condensation of 4-piperidone hydrochloride with substituted benzaldehyde under reflux led the formation of mono-carbonyl curcumin. The synthesized curcumin were further reacted with benzosulphonyl chloride by nucleophilic substitution of -NH group to afford 3,5-bis((E)-2metoksi benziliden)-1-(fenilsulfonil)piperidin-4-on (EN-BS) compounds with excellent yield, 94\%. Structure of the synthesized compounds were confirmed by UV, IR, MS and NMR spectra analysis. All the synthesized compounds were screened for their toxicity activity using BSLT method. The result showed that compounds are toxic whereas the $L C_{50}$ is below 200 ppm.
\end{abstract}

Key word: Curcumin, synthesize curcumin, Brine Shrimp Lethality (BSLT)

\section{PENDAHULUAN}

Kurkumin merupakan senyawa fenolik yang terdapat dalam rimpang kunyit (Curcuma longa L.) dengan aktivitas biologi sebagai antioksidan, antiinflamasi, kemopreventif dan kemoterapi. Kurkumin juga memiliki aktivitas sebagai antikanker, antimutagenik, antikoagulan, antifertilitas, antidiabetes, antibakteri, antijamur, antiprotozoa, antivirus, dan antifibrosis (Chattopadhyay et al., 2004). Di India, Cina, dan negara-negara Asia Tenggara seperti Indonesia, zat warna kuning dari kurkuma dimanfaatkan sebagai bahan tambahan makanan, bumbu, maupun obatobatan, yang tidak bersifat toksik. Kurkumin ditemukan pada berbagai genus Curcuma dan merupakan pigmen kuning pada tanaman Curcuma longa L. Di alam, kurkumin selalu terdapat bersama-sama dengan dua senyawa turunan lainnya yaitu demetoksi kurkumin dan bis- demetoksi kurkumin, yang dikenal dengan nama kurkuminoid (Badreldin et al., 2006).

Modifikasi senyawa kurkumin pada cincin aromatis dapat menghasilkan senyawa analog kurkumin yang memiliki aktivitas biologis yang lebih baik dibandingkan senyawa kurkumin. Sintesis kurkumin dapat dilakukan dengan reaksi kondensasi aldol. Sintesis dapat dilakukan dalam suasana asam (Selvakumar. B dan Venkataraman. R, 2002) maupun dalam suasana basa.

Kurkumin hasil sintesis dapat dikelompokkan menjadi dua kelompok utama yaitu derivat kurkumin dan analog kurkumin. Derivat kurkumin dibatasi pada senyawa yang masih mempertahankan bentuk dasar senyawa kurkumin $(-\mathrm{C}=\mathrm{C}$ $\mathrm{CO}-\mathrm{CH}_{2}-\mathrm{CO}-\mathrm{C}=\mathrm{C}-$ ). Derivatisasi terhadap senyawa kurkumin adalah dengan asetilasi, alkilasi, glikosilasi, aminoasilasi. Analog kurkumin merupakan senyawa yang relatif 
berbeda dengan bentuk dasar kurkumin. Analog kurkumin dapat diperoleh dari penyederhanaan gugus beta diketo menjadi gugus monoketo dan variasi pada enon ataupun ena pada C7 linker. Analog kurkumin telah banyak disintesis dengan tujuan untuk meningkatkan stabilitas, meningkatkan potensi dan selektivitas aktivitas biologisnya, (Da'i, 2010). Penelitian yang telah dilakukan oleh (Eryanti et al., 2011 ) menghasilkan senyawa analog kurkumin yaitu $(2 E, 5 E)$ 2,5-dibenziliden-siklopentanon, (2E,5E)2,5-bis-(4-hidroksi-benzeliden)-

siklopentanon yang bersifat toksik dan (2E,5E)-2,5-bis-(4-dimetil-amin-

benziliden)-siklopentanon yang bersifat sebagai antioksidan.

Berdasarkan uraian di atas, pada penelitian ini telah dilakukan sintesis senyawa analog kurkumin 3,5-bis $((E)$ metoksibenziliden)-1-(fenilsulfonil)

piperidin-4-on menggunakan metode refluks. Senyawa hasil sintesis ini akan diuji aktivitas biologisnya melalui uji toksisitas menggunakan metode Brine Shrimp Lethality Test (BSLT).

\section{METODE PENELITIAN}

\section{Alat dan Bahan}

Peralatan yang digunakan adalah oven microwave (Samsung ME109F), ultrasonik $\left(\mathrm{Ney}^{\circledR}\right)$, satu set alat destilasi, neraca analitik, pompa vakum, corong Buchner, chamber KLT, alat penentu titik leleh Fisher John (SMP 11-Stuart ${ }^{\circledR}$ ), pipet mikro, lampu UV (Camag ${ }^{\circledR} 254$ dan 366 $\mathrm{nm})$ spektrofotometer UV-Visible (Genesys 10S UV-VIS v4.002 2L9N175013), HPLC (UFLC ProminanceSintesis senyawa analog kurkumin 3,5bis $((E)$-metoksi benziliden)-1(fenilsulfonil)piperidin-4-on (EN-BS)
Shimadzu LC Solution, detektor UV SPD 20AD), spektrofotometer FTIR (FTIR Shimadzu, IR Prestige-21), spektrometer massa (Water LCT premier XE mode positif), spektrometer NMR (Agilent 500 $\mathrm{MHz}$ dengan sistem konsol DD2), serta alat-alat gelas yang umum digunakan di Laboratorium Kimia FMIPA. Bahan bahan yang digunakan adalah 2metoksibenzaldehid (Sigma-Aldrich), 3metoksibenzaldehid (Merck), 4metoksibenzaldehid (Merck), 4-piperidon (Sigma-Aldrich), etanol absolut (Merck), kalium hidroksida $(\mathrm{KOH})$, indikator universal, pelat KLT $\mathrm{GF}_{254}$ (Merck), metanol, $n$-heksana, etilasetat dan aqua DM.

\section{Prosedur Penelitian}

Sintesis senyawa analog kurkumin 3,5bis((E)-metoksi benziliden)piperidin-4on (EN)

Campuran senyawa 4-piperidon (5,0 mmol) dan metoksibenzaldehid (10,0 mmol) dilarutkan dalam pelarut etanol 20,0 $\mathrm{mL}$, kemudian ditambahkan tetes demi tetes $\mathrm{KOH}(10 \%, 10,0 \mathrm{~mL})$. Campuran tersebut di refluks pada suhu $80^{\circ} \mathrm{C}$ dan reaksi dikontrol tiap 30 menit dengan KLT. Setelah reaksi selesai, campuran dinetralkan dengan $\mathrm{HCl} 10 \%$, lalu didiamkan pada lemari pendingin selama 24 jam. Padatan yang diperoleh disaring menggunakan corong Buchner dan dicuci dengan $n$-heksan dan aqua DM. Kemurnian senyawa hasil sintesis, dianalisis dengan KLT. Padatan yang tidak murni direkristalisasi dengan metanol.

Senyawa kurkumin (1,0 $\mathrm{mmol})$, cesium karbonat $(1,5 \mathrm{mmol})$ dilarutkan dalam asetonitril 20,0 mL. Benzosulfonil klorida (1,0 mmol) ditambahkan tetes demi 
tetes kedalam campuran, kemudian campuran tersebut di refluks pada suhu $80^{\circ} \mathrm{C}$ selama 12 jam. Reaksi dikontrol tiap 2 jam dengan kromatografi lapis tipis. Setelah reaksi selesai, campuran diuapkan dengan rotary evaporator. Padatan yang diperoleh diekstrak menggunakan pelarut air:etil asetat. Senyawa yang diperoleh dicuci dengan $n$-heksan dan aqua DM. Kemurnian senyawa hasil sintesis, dianalisis dengan KLT, HPLC dan penentuan titik leleh. Padatan yang tidak murni direkristalisasi dengan metanol.

\section{Identifikasi struktur senyawa}

Senyawa analog kurkumin murni yang diperoleh diidentifikasi strukturnya melalui analisis spektroskopi UV, FTIR, NMR dan HRMS. Analisis UV dan FTIR dilakukan di Jurusan Kimia FMIPA UR, sedangkan analisis HRMS di Universitas Padjajaran dan analisis NMR dilakukan di Institut Teknologi Bandung.

\section{Uji toksisitas dengan metode BSLT}

Masing-masing sebanyak 5,0 mg senyawa kurkumin dilarutkan dengan $5 \mathrm{~mL}$ metanol sehingga menghasilkan larutan induk $1.000 \mu \mathrm{g} / \mathrm{mL}$. Kemudian dari larutan induk dibuat konsentrasi yang berbeda melalui pengenceran bertingkat yaitu 100,0, 10,0, 1,0 dan 0,1 $\mu \mathrm{g} / \mathrm{mL}$. Larutan sampel dipipet ke dalam masing-masing vial sebanyak $0,5 \mathrm{~mL}$, lalu pelarut diuapkan hingga kering. Sampel uji dilarutkan kembali dengan 50,0 $\mu \mathrm{L}$ DMSO, kemudian ditambahkan 2,0 mL air laut. Sebanyak 10 ekor larva udang $A$. salina dimasukkan ke tiap-tiap vial dan ditambahkan lagi dengan air laut sampai batas kalibrasi 5,0 mL. Vial lain yang terkalibrasi juga disiapkan sebagai kontrol. Vial tersebut berisi 50,0 $\mu \mathrm{L}$ DMSO tanpa senyawa uji dan diperlakukan sama seperti vial dengan senyawa uji. Selanjutnya vial uji dan kontrol dibiarkan selama 24 jam. Jumlah larva udang A. salina yang mati dihitung dan dicatat. Tingkat toksisitas diukur dengan melihat persentase larva yang mati. Pengujian dilakukan sebanyak tiga kali pengulangan dengan perlakuan sama untuk masing-masing konsentrasi. Data yang diperoleh dianalisis untuk menentukan nilai $\mathrm{LC}_{50}$ dengan metode kurva menggunakan tabel analisis probit.

\section{HASIL DAN PEMBAHASAN}

Hasil sintesis senyawa analog kurkumin 3,5-bis $((E)-2-$

\section{metoksibenziliden)piperidin-4-on (EN)}

Senyawa murni yang diperoleh berupa padatan kuning dengan massa 1,174 $\mathrm{g}$ dan rendemen yang diperoleh sebesar 70 $\%$, Titik leleh senyawa yang diperoleh 182$184^{\circ} \mathrm{C}$

\section{Gambar 1. Struktur EN}<smiles>O=C1CCNCC1</smiles><smiles>COc1ccccc1C=O</smiles><smiles>CCOCC</smiles><smiles>COc1ccccc1/C=C1\CNC/C(=C\c2ccccc2OC)C1=O</smiles>

melalui reaksi kondensasi aldol atau yang dikenal sebagai reaksi Claisen-Schmidt. Reaksi ini lebih umum dikenal untuk sintesis senyawa kalkon. Pada dasarnya, 
perbedaan sintesis senyawa kalkon dan kurkumin adalah rasio senyawa keton dan aldehid yang direaksikan yaitu rasio 1:1 untuk sintesis senyawa kalkon dan 1:2 untuk sintesis senyawa kurkumin. Selain itu, pada sintesis senyawa kurkumin, senyawa keton harus memiliki dua hidrogen $\alpha$ yang simetris sebagai situs reaksi.

Senyawa EN yang disintesis, merupakan senyawa kurkumin yang telah disintesis oleh Eryanti (2014). Sehubungan dengan hal tersebut, dilakukan modifikasi metode sintesis agar memperoleh rendemen yang lebih tinggi. Sebelumnya Eryanti (2014), telah mensintesis senyawa target EN dengan rendemen 67,1\% menggunakan katalis asam dan metode iradiasi gelombang mikro. Pada penelitian ini, senyawa EN disintesis dengan menggunakan katalis basa $\mathrm{KOH}$ dan metode refluk yang masing-masing diperoleh dengan rendemen 70\%. Hasil tersebut menunjukkan penggunaan katalis basa $\mathrm{KOH}$ dan metode refluk lebih baik dalam sintesis kurkumin. Senyawa EN telah disintesis, diidentifikasi dengan uji KLT dan pengukuran titik leleh. Uji KLT dan pengukuran titik leleh dilakukan dengan membandingkan senyawa EN dengan senyawa kurkumin yang telah disintesis oleh Eryanti (2014) sebagai standar. Pengukuran titik leleh juga menunjukkan range yang sama dengan kurkumin Eryanti (2014), yaitu $182-184^{\circ} \mathrm{C}$

Sintesis senyawa analog kurkumin 3,5bis $((E)$-metoksi benziliden)-1(fenilsulfonil) piperidin-4-on (EN-BS)

Senyawa analog kurkumin 3,5-
benziliden)-1-
bis $((E)$-metoksi
(fenilsulfonil) piperidin-4-on merupakan
hasil reaksi lanjutan dari kurkumin EN,
dalam hal ini, kurkumin yang telah

disintesis direaksikan dengan benzosulfonil klorida melalui reaksi subtitusi pada gugus -NH yang dibantu oleh katalis $\mathrm{Cs}_{2} \mathrm{CO}_{3}$ untuk menghasilkan senyawa analog kurkumin. Reaksi ini dikatalis oleh $\mathrm{Cs}_{2} \mathrm{CO}_{3}$ bersifat sebagai basa yang akan mengikat atom $\mathrm{H}$ pada gugus $-\mathrm{NH}$ kurkumin sehingga membentuk ion $\mathrm{N}^{-}$yang bersifat nukleofilik. Kemudian, ion $\mathrm{N}^{-}$akan menyerang atom $\mathrm{S}$ pada benzosulfonil klorida yang bersifat elektrofil akibat adanya gaya tarik dari atom-atom elektronegatif seperti $\mathrm{O}$ dan $\mathrm{Cl}$, sehingga terbentuk senyawa analog kurkumin. Mekanisme reaksi pembentukan senyawa analog kurkumin EN-BS dapat dilihat pada gambar 2.

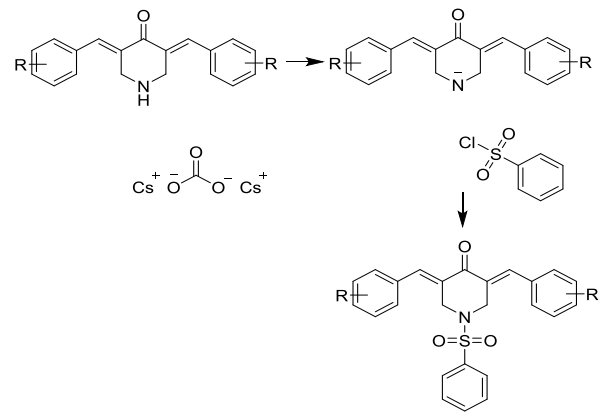

Gambar 2. Mekanisme reaksi senyawa analog kurkumin EN-BS

Produk hasil sintesis dipisahkan dari pelarutnya menggunakan rotary evaporator. Kemudian padatan yang diperoleh dimasukkan ke dalam corong pisah dan diekstraksi menggunakan system palarut yang tidak saling bercampur yaitu air : etilasetat. Dalam hal ini, senyawa kurkumin akan larut dalam pelarut etilasetat, sedangkan katalis $\mathrm{Cs}_{2} \mathrm{CO}_{3}$ berlebih akan larut dalam air, sehingga produk kurkumin dapat dipisahkan dengan mengambil lapisan etil asetat. Selanjutnya, lapisan etil asetat tersebut dicuci dengan $\mathrm{NaHCO}_{3}$ untuk mengikat $\mathrm{H}_{2} \mathrm{CO}_{3}$ yang terbentuk sebagai produk samping hasil reaksi. Endapan diperoleh dengan 
memekatkan lapisan etilasetat menggunakan rotary evaporator, sehingga diperoleh senyawa EN-BS dengan rendemen yang sangat memuaskan yaitu $91 \%$.

Senyawa EN-BS diidentifikasi strukturnya menggunakan analisis spektroskopi UV, FTIR, ${ }^{1} \mathrm{H}-\mathrm{NMR},{ }^{13} \mathrm{C}$ NMR dan HRMS. Spektrum UV senyawa EN-BS menunjukkan serapan pada panjang gelombang $206 \mathrm{~nm}$ dan $365 \mathrm{~nm}$. Serapan pada panjang gelombang $206 \mathrm{~nm}$ menunjukkan adanya transisi electron dari orbital $\pi \rightarrow \pi^{*}$ cincin benzosulfonil, sedangkan serapan pada panjang gelombang $353 \mathrm{~nm}$ menunjukkan adanya transisi electron dari orbital $\pi \rightarrow \pi^{*}$ sistem sinamoil. Serapan sistem sinamoil terdapat pada panjang gelombang lebih besar dikarenakan panjangnya system konjugasi system sinamoil mengakibatkan terjadinya splitting orbital $\pi$, sehingga energi yang dibutuhkan untuk mengeksitasi electron $\pi$ lebih kecil.

Spektrum FTIR senyawa EN-BS menunjukkan serapan pada bilangan gelombang $\left(\mathrm{cm}^{-1}\right)$ 3024, 2969, 1675, 1608, 1351 dan 1251. Serapan pada bilangan gelombang $3024 \mathrm{~cm}^{-1}$ menunjukkan vibrasi ikatan C-H aromatik dari cincin fenil, sedangkan serapan pada bilangan gelombang $2969 \mathrm{~cm}^{-1}$ menunjukkan adanya vibrasi dari ikatan $\mathrm{C}-\mathrm{H}$ alifatik dari gugus metoksi serta cincin piperidon. Selain itu, adanya serapan pada bilangan gelombang 1675 dan $1608 \mathrm{~cm}^{-1}$ yang masing-masing menunjukkan vibrasi ikatan $\mathrm{C}=\mathrm{O}$ dan $\mathrm{C}=\mathrm{C}$ alkena mengindikasikan adanya gugus enon dari senyawa kurkumin. Serapan pada bilangan gelombang $1351 \mathrm{~cm}^{-1}$ menunjukkan adanya vibrasi ikatan $\mathrm{S}=\mathrm{O}$, sedangkan pada bilangan gelombang 1251 $\mathrm{cm}^{-1}$ menunjukkan adanya vibrasi ikatan C$\mathrm{O}$ dari gugus metoksi. Pembentukan senyawa kurkumin hybrid dapat terlihat jelas pada perbandingan spektrum FTIR senyawa EN dengan senyawa EN-BS, dimana serapan pada bilangan gelombang $3246 \mathrm{~cm}^{-1}$ yang menunjukkan vibrasi ikatan $\mathrm{N}-\mathrm{H}$, sudah tidak tampak pada spectrum FTIR EN-BS yang mengkonfimasi pembentukan senyawa analog kurkumin.

Senyawa target merupakan molekul yang memiliki struktur yang simetris, sehingga ada beberapa proton dan karbon yang memiliki lingkungan yang sama dan muncul pada pergeseran kimia yang sama pula. Pada spektrum ${ }^{1} \mathrm{H}-\mathrm{NMR}$, terdapat puncak-puncak dengan orientasi dan integrasi yang mengindikasikan senyawa EN-BS sesuai dengan molekul target. Spektrum ${ }^{1} \mathrm{H}-\mathrm{NMR}$ EN-BS terbagi atas dua daerah yaitu downfield dan upfield. Pada daerah downfield terdapat puncak dari proton-proton yang lebih shielding, yaitu pada pergerasan $\delta 3,89$ terdapat puncak dengan orientasi singlet yang menunjukkan proton pada gugus $-\mathrm{OCH}_{3}$. Kemudian, pada $\delta \quad 4,49$ juga terdapat puncak berorientasi singlet yang menunjukkan proton $\mathrm{H} 2$ dan $\mathrm{H} 4$. Sedangkan pada daerah upfield terdapat puncak dari proton yang deshielding yaitu proton-proton dari cincin aromatic dan proton $\mathrm{H}_{\beta}$. Proton $\mathrm{H} 4{ }^{\prime}$ membentuk puncak triplet pada pergeseran $\delta$ 7,08 karena proton $\mathrm{H} 4$ ' memiliki kopling ortho terhadap proton $\mathrm{H} 3^{\prime}$ dan $\mathrm{H}^{\prime}$ ' $\left(J_{\mathrm{H} 4}{ }^{-}-\mathrm{H} 3^{\prime}\right.$ $=J_{\mathrm{H} 4^{\prime}-\mathrm{H} 5^{\prime}}=7,5 \mathrm{~Hz}$ ). Proton H3' membentuk puncak doublet pada pergeseran $\delta 7,16$ karena proton $\mathrm{H} 3$ ' memiliki kopling ortho terhadap proton $\mathrm{H}^{\prime}\left(J_{\mathrm{H} 3^{\prime}-\mathrm{H} 4^{\prime}}=8,5 \mathrm{~Hz}\right)$. Proton H6' membentuk puncak doublet pada pergeseran $\delta$ 7,24 karena proton H6' memiliki kopling ortho terhadap proton H5' $\left(J_{\mathrm{H} 6^{\prime}-\mathrm{H} 5^{\prime}}=7,7 \mathrm{~Hz}\right)$. Proton-proton aromatic lainnya ditemukan sebagai puncak multiplet pada pergeseran $\delta 7,55-7,44$. Sama halnya dengan puncak proton $\mathrm{H}_{\beta}$ 
yang tidak tampak secara jelas, karena muncul sebagai puncak multiplet pada pergeseran $\delta 7,73-7,66$ akibat overlapping dengan puncak dari proton $\mathrm{H} 4$ " dari cincin fenilsulfonil. Interpretasi data spectrum ${ }^{1} \mathrm{H}$ NMR dapat dilihat pada Tabel 1.

Pada spectrum ${ }^{13} \mathrm{C}$-NMR senyawa EN-BS menunjukkan puncak atom karbon dengan pergeseran kimia yang sesuai dengan senyawa target. Pada pergeseran kimia $\delta$ 184,6 ditemukan puncak dari karbon karbonil $(\mathrm{C}=\mathrm{O})$. Selain itu puncak dari karbon $\mathrm{C}^{\prime}$ yang berikatan dengan gugus $-\mathrm{OCH}_{3}$ serta puncak dari karbon $\mathrm{OCH}_{3}$ masing-masing ditemukan pada pergeseran kimia $\delta 158,4$ dan $\delta 56,1$. Pada pergeseran kimia $\delta \quad 127,7$ ditemukan puncak dari karbon yang mengikat $\mathrm{H}_{\beta}$. Sedangkan karbon C1" yang berikatan dengan gugus sulfonil ditemukan pada $\delta$ 137,6. Interpretasi data spektrum ${ }^{13} \mathrm{C}-\mathrm{NMR}$ dapat dilihat pada Tabel 1 .

Tabel 1. Interpretasi data spektroskopi NMR senyawa EN-BS

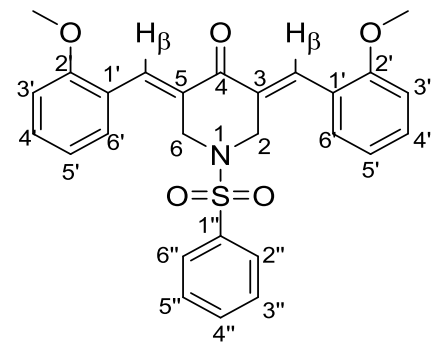

\begin{tabular}{ccc}
\hline Posisi & $\boldsymbol{\delta C}_{\mathbf{C}}(\mathbf{p p m})$ & $\boldsymbol{\delta}_{\mathbf{H}}(\mathbf{p p m})$ (Multiplisitas, J) \\
\hline$-\mathrm{OCH}_{3}$ & 56,1 & $3,89(\mathrm{~s})$ \\
2 & 47,4 & $4,49(\mathrm{~s})$ \\
3 & 133,9 & - \\
4 & 184,6 & - \\
5 & 133,9 & - \\
6 & 47,4 & $7,73-7,6 \mathrm{~s})$ \\
$\mathrm{C}_{\beta}$ & 127,7 & - \\
$1^{\prime}$ & 133,6 & - \\
$2^{\prime}$ & 158,4 & $7,16(\mathrm{~d}, J=8,5 \mathrm{~Hz})$ \\
$3^{\prime}$ & 112,0 & $7,08(\mathrm{t}, J=7,5 \mathrm{~Hz})$ \\
$4^{\prime}$ & 130,6 & $7,55-7,44(\mathrm{~m})$ \\
$5^{\prime}$ & 120,9 & $7,24(\mathrm{~d}, J=7,7 \mathrm{~Hz})$ \\
$6^{\prime}$ & 129,8 & - \\
$1^{\prime \prime}$ & 137,6 & $7,55-7,44(\mathrm{~m})$ \\
$2^{\prime \prime}$ & 130,8 & $7,55-7,44(\mathrm{~m})$ \\
$3^{\prime \prime}$ & 123,0 & $7,73-7,66(\mathrm{~m})$ \\
$4^{\prime \prime}$ & 132,1 & $7,55-7,44(\mathrm{~m})$ \\
$5^{\prime \prime}$ & 123,0 & $7,55-7,44(\mathrm{~m})$ \\
$6^{\prime \prime}$ & 130,8 &
\end{tabular}

*Spektrum ${ }^{1} \mathrm{H}-\mathrm{NMR}(500 \mathrm{MHz})$ dan ${ }^{13} \mathrm{C}-\mathrm{NMR}(125 \mathrm{MHz})$ dalam pelarut DMSO- $d_{6}$

Spektrum HRMS dari senyawa ENBS yang telah disintesis menunjukkan puncak ion molekul yang teramati sebagai $[\mathrm{M}+\mathrm{H}]^{+}$dengan $\mathrm{m} / \mathrm{z}$ 476,1558 dengan kelimpahan $100 \%$. Massa terhitung dari senyawa target dengan rumus molekul $\mathrm{C}_{27} \mathrm{H}_{26} \mathrm{NO}_{5} \mathrm{~S}$ menunjukkan $[\mathrm{M}+\mathrm{H}]^{+}=$
476,1532. Berdasarkan Journal of the American Chemical Society (JACS) spectrum MS diharuskan memiliki standar deviasi $<3 \mathrm{mDA}$. Perbandingan massa puncak ion molekul terhadap massa molekul terhitung menunjukkan selisih 2,6 mDA $(<3$ mDA), maka spectrum HRMS 
senyawa EN-BS telah sesuai dengan molekul target.

Berdasarkan hasil analisis data spektroskopi UV, FTIR, ${ }^{1} \mathrm{H}-\mathrm{NMR},{ }^{13} \mathrm{C}$ NMR dan HRMS menunjukkan bahwa senyawa EN-BS yang telah disintesis dari senyawa kurkumin EN dan benzosulfonil klorida pada penelitian ini sesuai dengan senyawa target yang diharapkan yaitu senyawa kurkumin 3,5-bis((E)-2-metoksi benziliden)-1-(fenilsulfonil) piperidin-4on.

\section{Hasil uji toksisitas senyawa kurkumin EN-BS}

Senyawa kurkumin EN-BS yang telah disintesis diuji toksisitasnya guna untuk mengetahui sifat toksiknya. Berdasarkan perhitungan diketahui senyawa kurkumin EN-BS dan memiliki harga $\mathrm{LC}_{50}$ yaitu $0,85 \mu \mathrm{g} / \mathrm{mL}$. Menurut

\section{DAFTAR RUJUKAN}

Anderson, J.E., Goetz, C.M. \& Laughlin, L.C. 1991. A blind comparison of simple bench-top bioassays and human tumour cell cytotoxicities as antitumor prescreens. Pytochemical Analisys, 2: 107-111.

Badreldin, H.A., Marrif, H., Salwa, A,N., dan Amel, O.B. 2006. Some

Biological Properties Of Curcumin.

Natural Product Communication. 1

(6): 509-521

Chattopadhyay, I., Biswas, K., Bandyopadhyay, U., Banerjee, R.K. 2004. Turmeric and curcumin: Biological actions and medicinal applications. Current Science, Vol $4: 1$

Da'i, M., Fajria, A dan Utami, W. 2010. Sintesis Senyawa Analog Kurkumin 3,5-bis-(4-hidroksi-3-
Anderson et al., (1991), suatu senyawa murni dikatakan memiliki sifat toksik jika memiliki harga $\mathrm{LC}_{50} \leq 200 \mu \mathrm{g} / \mathrm{mL}$. Berdasarkan hal tersebut, dapat disimpulkan bahwa senyawa kurkumin ENBS merupakan senyawa yang toksik.

\section{KESIMPULAN}

Berdasarkan penelitian yang telah dilakukan, maka dapat disimpulkan, analog senyawa kurkumin yaitu 3,5-bis((E)-2metoksi benziliden)-1(fenilsulfonil)piperidin-4-on telah berhasil disintesis dengan rendemen yang memuaskan yaitu $94 \%$. Identifikasi struktur melalui analisis spektroskopi UV, FTIR, HRMS dan NMR mengkonfirmasi senyawa EN1-BS sesuai dengan senyawa target. Senyawa kurkumin EN1-BS bersifat toksik dengan harga $\mathrm{LC}_{50}$ yaitu $0,85 \mu \mathrm{g} / \mathrm{mL}$.

metoksibenzilidin) Piperidin4-on (Monohidrat Hidroklorida) dengan Katalis HCl. Pharmacon. 11(1): 3338.

Eryanti, Y., 2014. Sintesis Senyawa Analog Kurkumin Serta Aktivitas Sitotoksiknya Terhadap Sel Murin Leukemia P-388 dan Sel promielositik leukemia Manusia Hl60. Disertasi. Bandung: Universitas Padjajaran

Da'i, M., Fajria, A dan Utami, W. 2010. Sintesis Senyawa Analog Kurkumin 3,5-bis-(4-hidroksi-3-

metoksibenzilidin) Piperidin4-on (Monohidrat Hidroklorida) dengan Katalis HCl. Pharmacon. 11(1): 3338.

Pandey, A., Kumar, R. dan Srivastava, R. 2010. Curcumin-the yellow magic. Internasional Journal Pharmacol, 4: 343-354 
Selvakumar. B dan Venkataraman. R. (2002). Synthesis and Biological Evaluation of Some Curcumin
Analogs and Their Derivatives. Journal Chemical. 3(2) :260-265 